\title{
Synthesis of 1,3-0xazepine Derivatives Derived from 2-(1H-Benzo[d][1,2,3]Triazol-1-yl) Acetohydrazide by Using Microwave Irradiation
}

\author{
Nihad Ismail Taha \\ Department of Chemistry, College of Science, Kirkuk University, Kirkuk, Iraq \\ Email: Nihad_ismael @yahoo.com
}

How to cite this paper: Taha, N.I. (2017) Synthesis of 1,3-Oxazepine Derivatives Derived from 2-(1H-Benzo[d][1,2,3]Triazol-1yl) Acetohydrazide by Using Microwave Irradiation. International Journal of Organic Chemistry, 7, 219-228.

https://doi.org/10.4236/ijoc.2017.73016

Received: January 4, 2017

Accepted: July 18, 2017

Published: July 21, 2017

Copyright $\odot 2017$ by author and Scientific Research Publishing Inc.

This work is licensed under the Creative

Commons Attribution International

License (CC BY 4.0).

http://creativecommons.org/licenses/by/4.0/

\begin{abstract}
A series of Schiff base and their derivative (oxazepine) have been synthesized. 8-hydrazone(schiff-bases) derivatives type (E)-2-(1H-benzo[d] [1,2,3]triazole$1-\mathrm{yl}$ )-N-(substituted benzylidene)acetohydrazide were prepared by condensation $1 \mathrm{H}$-benzo[d][1,2,3] triazol-1-yl)hydrazine with various aromatic aldehyde in ethanol in the presence of dimethyl formamid or acetic acid as catalyst by using MWI to yield the Schiff bases. These Schiff's base on treatment with Maleic anhydride in dry conditions by using MWI to give 7-membered heterocyclic ring system (oxezapine) of $(2-(1 \mathrm{H})$ benzo[d] $[1,2,3]$ triazol-1-yl)-N-(2(substituted penyl)-4, 7-dioxo-4,7-dihydro-1,3-oxazepin-3-(2H)-yl)acetamide. The purity of the compounds was confirmed by TLC. The final products were identified by their melting point, IR, 1HNMR, and UV-visible spectra.
\end{abstract}

\section{Keywords}

Hydrazone, Microwave, Oxezapine, Benzotriazole, Hydrazine

\section{Introduction}

The Schiff bases (or hydrazones) are considered to be precusor of (oxazepine) and other heterocyclic rings. Oxazepine, refers to any seven-membered ring containing oxygen in position one and nitrogen in position three in addition to the five carbon atoms. The 1,3-oxazepine is a branch of many types of heterocyclic oxazepine [1]-[6]. The core structure is 1,3-oxazepine-4,7-diones of sevenmembered ring along with two carbonyl group. Over the years, the synthesis of oxazepine has been investigated and documented. It is prepared by the pericyc- 
liccyclo addition of Schiff base or hydrazone with maleic, phthalic and succinic anhydrides [7] [8] [9] [10] [11] and also by green chemistry method [12] [13]. Oxazepine derivatives were found to exhibit a vast variety of biological activities like antibacterial [14], antifungal [15], hypnotic muscle relaxant [16], antagonistic [17], inflammatory [18] and antiepileptic [19]. Microwave-assisted reactions within shorter time are becoming popular for organic chemists [20] [21] [22] and had recently been reviewed [23] [24]. More interest has been focused on dry media synthesis under microwave irradiation and especially by carrying out the experiments with supported reagents on mineral oxide [25] [26]. This technology provides a promising alternative to environmentally unacceptable thermol procedures, which are usually time consuming, unsafe and cause solvent emission leading to pollution and wastedisposal problems. Under the framework of green chemistry an environmentally benign solvent-free approach has been developed for the synthesis of substituted hydrazide, substituted hydrazones and oxazepine by using microwave-assisted dry media reaction conditions.

\section{Experimental}

Melting pionts were determined in open capillary tubes and are uncorrected by using Stuart Melting Point Apparatus. The IR spectra $\left(\mathrm{cm}^{-1}\right)$ were recorded on Schimadzu FT-IR-8400S by using $\mathrm{KBr}$ disc. ${ }^{1} \mathrm{HMNR}$ spectra $\left(\mathrm{DMSO}-\mathrm{d}_{6}\right.$ ) were recorded on ultra shield $300 \mathrm{MHz}$ Bruker (2003) NMR spectrometer using TMS as internal standard. Follow up of the reactions and the purity of the compounds by using TLC-techniqe on aluminium plates percoated with silica gel in various solvent system using iodine vapours as detecting agent. Reactions were carried out in domestic microwave oven (Bomann 02227 CB 700W). All the chemicals and solvents used were of laboratory grad.

\subsection{Preparation of Ethyl Benzotriazole Acetate(1a)}

$(0.03 \mathrm{~mol})$ of benzotriazole was mixed with $(0.03 \mathrm{~mol})$ of ethyl $-\alpha$-chloro acetate and $(9.0 \mathrm{gm})$ of potassium carbonate dry in $(70 \mathrm{~mL})$ of acetone for $24 \mathrm{hr}$. After completation of the reaction the solvent was evaporated, the product was extracted by using diethyl ether. Evaporating the organic solvent (diethyl ether) gave soild needle crystals, its physical data illustrated in Table 1, yield (60-90\%), M.p. $\left(60^{\circ} \mathrm{C}-61^{\circ} \mathrm{C}\right)$.

\subsection{General Procedure for Microwave Assisted Preparation of: 2-(1H-Benzo[d][1,2,3]Triazol-1-yl)Acetohydrazide (2a)}

( $0.01 \mathrm{~mol})$ of ester(1a)was mixed with $(0.01 \mathrm{~mol})$ hydrazine hydrate $(80 \%$ conc.) in a $50 \mathrm{~mL}$ beaker, then was $2 \mathrm{~mL}$ of methanol added to the mixture. The mixture was exposed to microwave irradiation $(80 \mathrm{~W})$ for about $3 \mathrm{~min}$. The progress of the reaction and the purity of the compounds were monitored with (TLC). The reaction mixture was cooled at $4^{\circ} \mathrm{C}-5^{\circ} \mathrm{C}$. The separated soild crystals were filtered and washed with cold ethanol. The crystals were dried and recrystallized from ethanol its physical data illustrated in Table 1. 
Table 1. Physical data for starting compounds.

\begin{tabular}{|c|c|c|c|c|c|c|c|}
\hline $\begin{array}{l}\text { Comp. } \\
\text { No. }\end{array}$ & Structure & Name & M.P. ${ }^{\circ} \mathrm{C}$ & Yield \% & MWI & $\begin{array}{l}\text { Reaction } \\
\text { time }\end{array}$ & Colour \\
\hline $1 \mathrm{a}$ & & ethyl 2-(1H-benzo[d] $[1,2,3]$ triazol-1-yl)acetate & $60-61$ & 73 & - & $24 \mathrm{hr}$ & white \\
\hline $2 \mathrm{a}$ & & 2-(1H-benzo[d] $[1,2,3]$ triazol-1-yl)acetohydrazide & $172-173$ & 95 & $80 \mathrm{~W}$ & $3 \mathrm{~min}$ & grayish \\
\hline
\end{tabular}

\subsection{General Procedure for Microwave-Assisted Preparation of:}

(E)-2-(1H-Benzo[d][1,2,3] Triazol-1-yl)-N'-(Substituted

Benzylidene)Acetohydrazide( $3 b, 4 b, 5 b, 6 b, 8 b, 9 b)$

(0.01 mol) of hydrazide(2) mixed with $(0.01 \mathrm{~mol})$ substituted aromatic aldehyde (2-hydroxy,3-hydroxy, 3-chloro,4-dimethylamino, 2-bromo, 4-bromo)in beaker size $50 \mathrm{~mL}, 3$ - 4 drops of dimethyl formaimde was added as catalyst. The mixture was exposed to microwave irradiation at different power and time interval (as showed in the Table 2). After completion of the reaction as indicated by TLC, the reaction mixture was cooled at room temperature and washed with mixed solvent (9:1) (ether: ethyl acetate). The products were recrystallized absolute ethanol to give yield $(60 \%-90 \%)$ pure crystal of substituted hydrazones ( 3 , $4,5,6,8,9)$.

The same procedure to prepare $(7 \mathrm{~b}, 10 \mathrm{~b})$ was followed using $(0.01 \mathrm{~mol})$ furfuraldehyde and $(0.01 \mathrm{~mol})$ cinnimaldehyde. its physical data illustrated in Table 2).

\subsection{General Procedure for Microwave-Assisted Preparation of: 2-(1H-Benzo[d][1,2,3]Triazol-1-yl)-N-(2-(Substituted Phenyl)-4,7-Dioxo-4,7-Dihydro-1,3-0xazepin-3(2H)-yl) Acetamide(11c,12c,13c,14c,15c,16c,17c,18c)}

$(0.001 \mathrm{~mol})$ of substituted hyrazone mixed with $(0.001 \mathrm{~mol})$ of maleic anhydride in dry poceline mortar, to obaine fine mixed powder. The dry powder was irradiated in a microwave oven at different power and time of irradiation(showed in the Table 3) in $50 \mathrm{~mL}$ open small beaker. After completion of the reaction as indicated by TLC, the reaction mixture was cooled at room temperature. The product was washed with benzene and recrystallizated by dioxane to give good yield $(60 \%-90 \%)$ of pure crystal oxazepine derivatives (11 - 18). its physical data illustrated in Table 3.

\section{Result and Discussion}

The Schiff base or (hydrazone) compounds [3b-10b] were synthesized from the reaction of benzotriazole acetohydrazide with different substituted aldehydes (Scheme 1). The synthesis of these compounds was carried out according to the steps outlined in scheme, by using microwave irradiation, and the physical properties are given in Table 2 . Table 4 describe the important vibrational 
Table 2. Physical data for hydrazone derivatives.

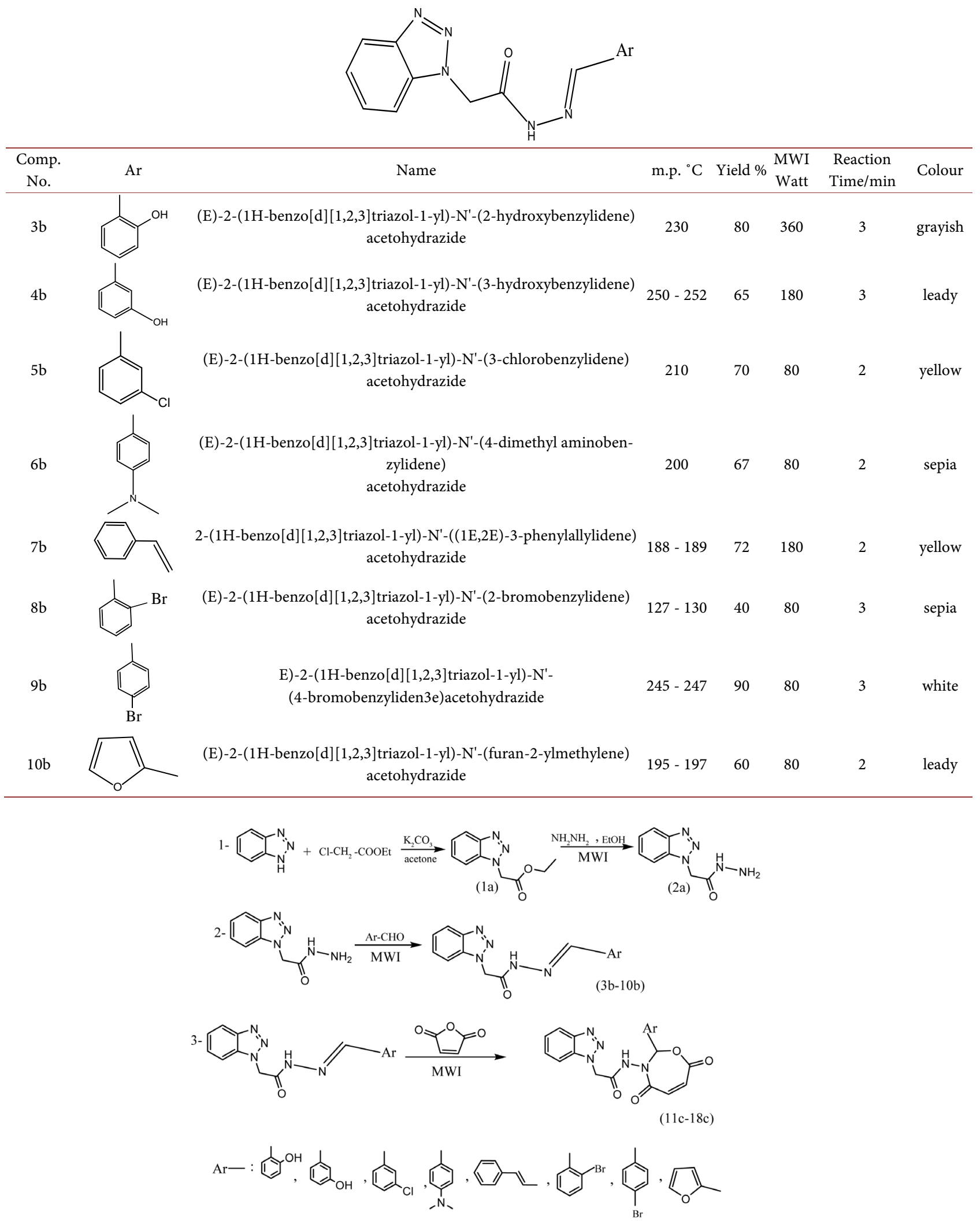

Scheme 1. The steps of synthesis. 
Table 3. Physical data for oxazepine derivatives.

\begin{tabular}{|c|c|c|c|c|c|c|c|}
\hline Comp. No. & $\mathrm{Ar}$ & Name & M.P. ${ }^{\circ} \mathrm{C}$ & Yield \% & $\begin{array}{l}\text { MWI } \\
\text { Watt }\end{array}$ & $\begin{array}{l}\text { Reaction } \\
\text { Time/min }\end{array}$ & Colour \\
\hline $11 \mathrm{c}$ & & $\begin{array}{l}\text { 2-(1H-benzo[d][1,2,3]triazol-1-yl)-N-(2-(2-hydroxyphenyl)-4, } \\
\text { 7-dioxo-4,7-dihydro-1,3-oxazepin-3(2H)-yl)acetamide }\end{array}$ & $150-152$ & 90 & 360 & 3 & leady \\
\hline $12 \mathrm{c}$ & & $\begin{array}{l}\text { 2-(1H-benzo[d][1,2,3]triazol-1-yl)-N-(2-(3-hydroxyphenyl)-4, } \\
\text { 7-dioxo-4,7-dihydro-1,3-oxazepin-3(2H)-yl)acetamide }\end{array}$ & $87-90$ & 85 & 180 & 3 & black \\
\hline $13 c$ & & $\begin{array}{l}\text { 2-(1H-benzo[d][1,2,3]triazol-1-yl)-N-(2-(3-chlorophenyl)-4,7 } \\
\text {-dioxo-4,7-dihydro-1,3-oxazepin-3(2H)-yl)acetamide }\end{array}$ & $140-142$ & 76 & 180 & 3 & gryisha \\
\hline $14 \mathrm{c}$ & & $\begin{array}{c}\text { 2-(1H-benzo[d] }[1,2,3] \text { triazol-1-yl)-N-(2-(4-dimethylaminoph } \\
\text { enyl)-4,7-dioxo-4,7-dihydro-1,3-oxazepin-3 } \\
\text { (2H)-yl)acetamide }\end{array}$ & $120-123$ & 78 & 180 & 2.5 & red \\
\hline $15 c$ & & $\begin{array}{c}\text { (E)-2-(1H-benzo[d] }[1,2,3] \text { triazol-1-yl)-N- } \\
(4,7 \text {-dioxo-2-styryl-4,7-dihydro-1,3-oxazepin-3 } \\
(2 \mathrm{H}) \text {-yl)acetamide }\end{array}$ & $112-115$ & 85 & 180 & 3 & yellow \\
\hline $16 c$ & & $\begin{array}{l}\text { 2-(1H-benzo[d][1,2,3]triazol-1-yl)-N-(2-(2-bromophenyl)-4,7 } \\
\text {-dioxo-4,7-dihydro-1,3-oxazepin-3(2H)-yl)acetamide }\end{array}$ & $135-137$ & 70 & 180 & 2 & gryisha \\
\hline $17 \mathrm{c}$ & $\mathrm{Br}$ & $\begin{array}{l}\text { 2-(1H-benzo[d][1,2,3]triazol-1-yl)-N-(2-(4-bromophenyl)-4,7 } \\
\text {-dioxo-4,7-dihydro-1,3-oxazepin-3(2H)-yl)acetamide }\end{array}$ & $124-126$ & 60 & 180 & 2.5 & yellow \\
\hline $18 \mathrm{c}$ & & $\begin{array}{c}\text { 2-(1H-benzo[d] }[1,2,3] \text { triazol-1-yl)-N-(2-(furan-2-yl)-4,7-diox } \\
\text { o-4,7-dihydro-1,3-oxazepin-3(2H)-yl)acetamide }\end{array}$ & $80-82$ & 68 & 360 & 3.5 & chestnut \\
\hline
\end{tabular}

Table 4. IR and UV spectrum data for the synthesized compounds (3b-10b).

\begin{tabular}{|c|c|c|c|c|c|c|c|c|}
\hline \multirow{2}{*}{ Comp. No. } & \multicolumn{7}{|c|}{$I R \mathrm{v} \cdot \mathrm{cm}^{-1}(\mathrm{KBr})$} & \multirow{2}{*}{$\begin{array}{c}U V(\mathrm{EtOH}) \\
\lambda_{\max }\end{array}$} \\
\hline & $\mathrm{C}=\mathrm{O}$ lactone & $\mathrm{C}=\mathrm{O}$ amide & $\mathrm{C}-\mathrm{N}$ & $\mathrm{C}-\mathrm{O}-\mathrm{C}$ & $\mathrm{C}=\mathrm{C}-\mathrm{C}=\mathrm{O}$ & $\operatorname{Ar} C=C$ & Other & \\
\hline $11 \mathrm{c}$ & 1680 & 1610 & 1265 & 1160 sy 1259 as & 1409 & 1453 & $3320(\mathrm{OH})$ & 307 \\
\hline $12 \mathrm{c}$ & 1725 & 1632 & 1255 & 1080 sy 1278 as & 1580 & 1450 & $3378(\mathrm{OH})$ & 315 \\
\hline $13 c$ & 1715 & 1612 & 1265 & 1165 sy 1260 as & 1455 & 1433 & $746(\mathrm{C}-\mathrm{Cl})$ & 280 \\
\hline $14 \mathrm{c}$ & 1729 & 1660 & 1232 & 1065 sy 1285 as & 1590 & 1446 & & 296 \\
\hline $15 c$ & 1720 & 1651 & 1229 & 1059 sy 1266 as & 1507 & 1432 & $1622(\mathrm{C}=\mathrm{C})$ & 276 \\
\hline $16 c$ & 1722 & 1646 & 1238 & 1049sy 1276as & 1480 & 1447 & $624(\mathrm{C}-\mathrm{Br})$ & 284 \\
\hline $17 \mathrm{c}$ & 1756 & 1638 & 1242 & 1038sy 1266as & 1496 & 1422 & 653(C-Br) & 302 \\
\hline $18 \mathrm{c}$ & 1761 & 1621 & 1239 & 1122 sy 1271 as & 1510 & 1445 & & 298 \\
\hline
\end{tabular}


modes of Schiff bases. The infrared spectra of Schiff bases exhibited the absence of absorption bands at $\left(3345-3250 \mathrm{~cm}^{-1}\right)$ corresponding to stretching modes of $\mathrm{NH}_{2}$ group of benzotriazole acetohydrazide and at $\left(1700 \mathrm{~cm}^{-1}\right) \mathrm{C}=\mathrm{O}$ group of substituted benzaldehydes which refers to the formation of the Schiff bases as azomethine $\mathrm{C}=\mathrm{N}$ linkage. This was confirmed by the appearance of new bands at (1580 - 1630) $\mathrm{cm}^{-1}$ assignable to $\mathrm{C}=\mathrm{N}$ azomethine group. The table also describe the positions of the bands assigned to vibrational modes of amide $\mathrm{NH}$ groups at $(3120-3230) \mathrm{cm}^{-1}$ and $\mathrm{C}=\mathrm{O}$ group of amide at $(1660-1680) \mathrm{cm}^{-1}$. The reaction of Schiff bases [3b-10b] with maleic anhydride in dry condition by using microwave irradiation to give 1,3-oxazepine-4,7-dione derivatives. Cyclic addition reaction is achieved by ring formation, due to interaction between HOMO orbital of maleic anhydride with LUMO obital of $(-\mathrm{C}=\mathrm{N})$ group [27]. Table 5 describes the important vibrational modes of oxazepine. The infrared spectra of oxazepine exhibited the absence of absorption bands at $(1580-1630) \mathrm{cm}^{-1}$ as azomethine $\mathrm{C}=\mathrm{N}$ linkage and strong absorption for pure maleic anhydrid at (1800 - 1955) $\mathrm{cm}^{-1}$. But the formation of oxazepine was confirmed by the presence of a new strong band at $(1760-1680) \mathrm{cm}^{-1}$ due to $\mathrm{C}=\mathrm{O}$ group as lactone and $\mathrm{C}=\mathrm{O}$ group as amide (lactam) at $(1610-1660) \mathrm{cm}^{-1}$. The table also describe band assigned to vibrational modes of (C-O-C) group at $(1260-1280) \mathrm{cm}^{-1}$ as asymmetrical and the band assigned to $\mathrm{C}-\mathrm{N}$ was observed at $(1610-1660) \mathrm{cm}^{-1}$ as in Figure 1. This confirmed the assigned seven-membered ring structure. UV spectrum of compounds in the Table 4 and Table 5 showed an absorption $\lambda_{\max }$ (270 - 320) nm which was attributed to different transitions of electrons.

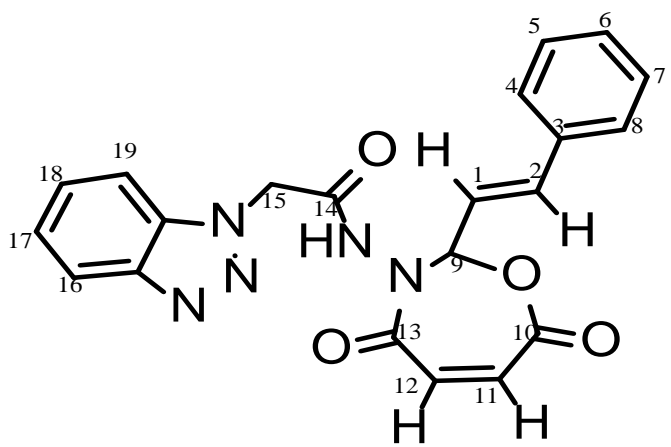

The ${ }^{1} \mathrm{HNMR}$ spectrum of compund ( $\mathrm{c}_{15}$ Figure 2 ) displayed a single peak appeared at $11.8 \mathrm{ppm}$ which was assigned to chemical shift of $\mathrm{NH}$ and multiplet peak at 7.3 - 7.8 ppm which were assigned to chemical shifts of aromatic protons at carbons $(4,5,6,7,8,16,17,18,19)$. The peak at $5.5 \mathrm{ppm}$ was attributed to the chemical shift of carbon (15) proton its between carbonyl amide and benzotriazol moiety. The signal related to the protons at carbons $(1,2)$ appeared at $5.9-6$ ppm due to conjegated with benzene ring. But protons at carbons $(11,12)$ in seven membered ring appeared at $6.1-6.3 \mathrm{ppm}$, the peak at $8.1 \mathrm{ppm}$ was attributed to the chemical shift of carbon (9) proton due to between two highly electronegativity atoms (oxygen and nitrogen). 


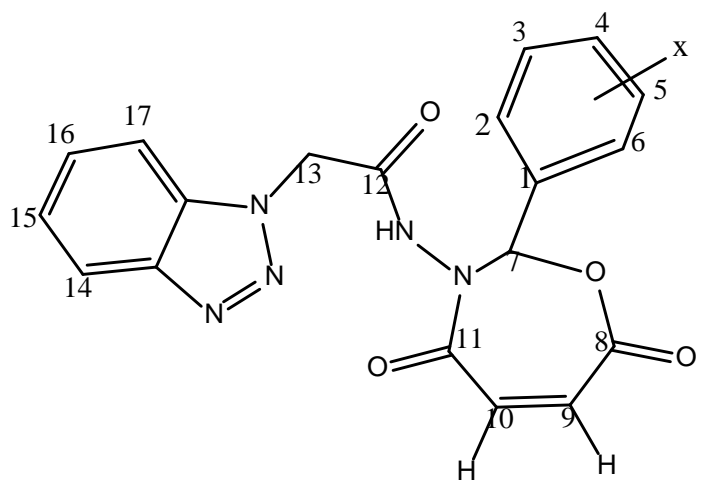

The 1HNMR spectrum of the compound (C11 Figure 3 ) displayed a single peak appeared at $11.8 \mathrm{ppm}$ which was assigned to chemical shift of $\mathrm{NH}$ and multiplet peak at 7.2 - 7.9 ppm which were assigned to chemical shifts of aromatic protons at carbons $(2,3,4,5,6,14,15,16,17)$. The peak at $5.5 \mathrm{ppm}$ was attri-

Table 5. IR and VUspectrum data for the synthesized compounds (11c-18c).

\begin{tabular}{|c|c|c|c|c|c|}
\hline \multirow{2}{*}{ Comp. No. } & \multicolumn{4}{|c|}{ IR $\mathrm{V} \cdot \mathrm{cm}^{-1}(\mathrm{KBr})$} & \multirow{2}{*}{$\begin{array}{c}\mathrm{UV}(\mathrm{EtOH}) \\
\lambda_{\max }\end{array}$} \\
\hline & $\mathrm{N}-\mathrm{H}$ & $\mathrm{C}=\mathrm{O}$ & $\mathrm{C}=\mathrm{N}$ & other & \\
\hline $3 b$ & 3115 & 1660 & 1607 & $3200(\mathrm{OH})$ & 318 \\
\hline $4 \mathrm{~b}$ & 3120 & 1671 & 1611 & $3191(\mathrm{OH})$ & 320 \\
\hline $5 b$ & 3190 & 1665 & 1599 & $738(\mathrm{C}-\mathrm{Cl})$ & 305 \\
\hline $6 \mathrm{~b}$ & 3211 & 1681 & 1619 & $1262(\mathrm{C}-\mathrm{N})$ & 317 \\
\hline $7 \mathrm{~b}$ & 3230 & 1669 & 1600 & $1619(\mathrm{C}=\mathrm{C})$ & 302 \\
\hline $8 b$ & 3220 & 1676 & 1580 & $624(\mathrm{C}-\mathrm{Br})$ & 309 \\
\hline $9 b$ & 3235 & 1680 & 1616 & $1110(\mathrm{C}-\mathrm{Br})$ & 310 \\
\hline $10 \mathrm{~b}$ & 3175 & 1662 & 1632 & $(\mathrm{C}-\mathrm{OC})$ & 303 \\
\hline
\end{tabular}

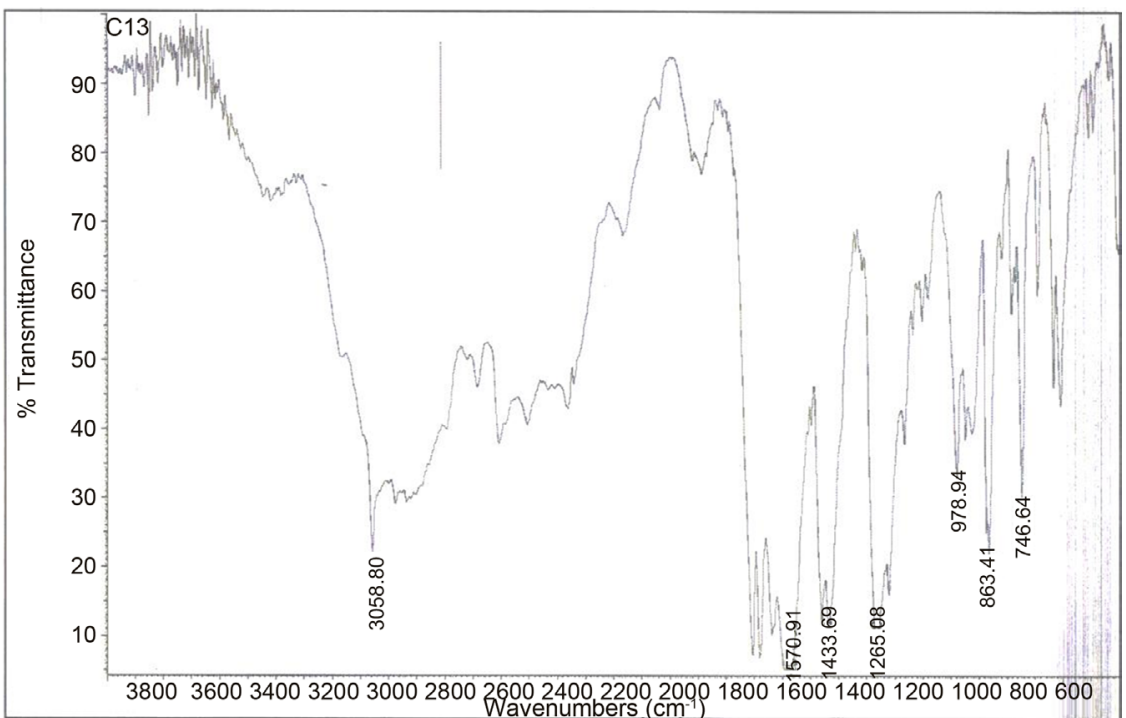

Figure 1. Infrared spectrum of 13C. 


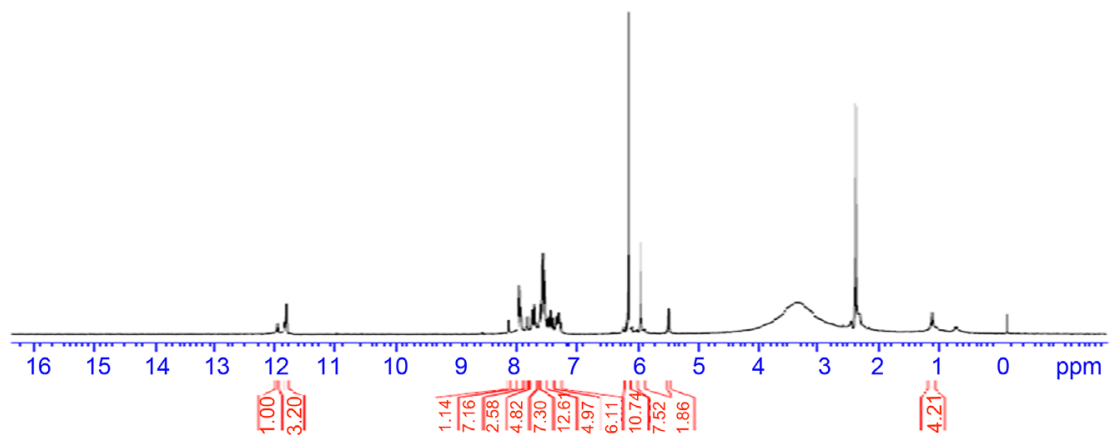

Figure 2. ${ }^{1} \mathrm{HNMR}$ spectrum of compound $15 \mathrm{c}$.

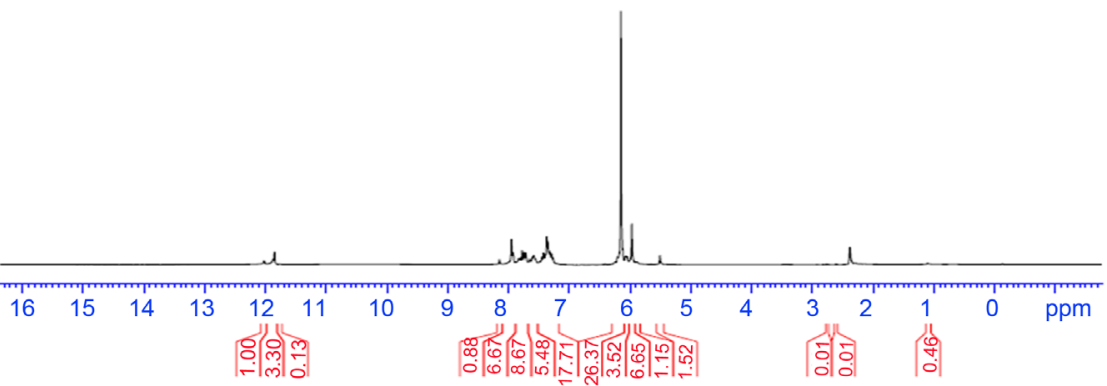

Figure $3 .{ }^{1} \mathrm{HNMR}$ spectrum of compound 11c.

Table 6. Proton NMR spectra data for the synthesis compounds (11c-18c).

\begin{tabular}{ccccccc}
\hline \multirow{2}{*}{$\begin{array}{c}\text { Comp. } \\
\text { No. }\end{array}$} & C-H aromatic & $\mathrm{CH}=\mathrm{CH}$ & $\mathrm{N}-\mathrm{H}$ & -CH2-aliphaticC-H (ring) & Others \\
\cline { 2 - 6 } $11 \mathrm{c}$ & $7.2-7.9$ & $6.3-6.9$ & 11.8 & 5.3 & 8.01 & $(\mathrm{OH}) 12$ \\
$12 \mathrm{c}$ & $7.15-8$ & $6.3-6.91$ & 10.9 & 5.4 & 8 & $(\mathrm{OH}) 9.01$ \\
$13 \mathrm{c}$ & $7.3-7.8$ & $6-6.92$ & 11.1 & 5.3 & 8.01 & \\
$14 \mathrm{c}$ & $7.1-8$ & $6.4-6.9$ & 11.3 & 5.3 & 7.9 & $\left(-\mathrm{N}\left(\mathrm{CH}_{3}\right)_{2}\right) 2.6$ \\
$15 \mathrm{c}$ & $7.2-7.8$ & $6.1-6.3$ & 11.9 & 5.4 & 8.1 & $\left(-\mathrm{CH}=\mathrm{CH}-\mathrm{CH}^{2}=5.9-6\right.$ \\
$16 \mathrm{c}$ & $6.9-7.7$ & $6.3-6.8$ & 11.1 & 5.6 & 7.9 & \\
$17 \mathrm{c}$ & $7-7.9$ & $6.2-6.9$ & 10.9 & 5.2 & 8 & \\
$18 \mathrm{c}$ & $7.1-7.9$ & $6.3-6.9$ & 11.2 & 5.4 & 8.02 & \\
\hline
\end{tabular}


buted to the chemical shift of carbon (13) proton its between carbonyl amide and benzotriazol moiety. The signal related to the protons at carbons $(9,10)$ appeared at $6.1-6.3 \mathrm{ppm}$ in seven membered ring, the peak at $8.1 \mathrm{ppm}$ was attributed to the chemical shift of carbon (7) proton due to between two highly electronegativity atoms (oxygen and nitrogen). The values of NMR are illustered in Table 6.

\section{References}

[1] Al-Harrasi, A. and Resissig, H.U. (2005) Ring Enliargment of Enantiopure 1,2Oxazine to 1,2-Oxazepine Derivaties and Their Palladium-Catalyzed Coupling. Synlett, 15, 2376-2378.

[2] Kumer, E.S. and Dhar, D.N. (1995) A Simple Ronte for the Synthesis of Oxazepine-2-One System Using Chlorosulfonyl Isocyanate. Synthetic Communications, 25, 1939-1945. https://doi.org/10.1080/00397919508015870

[3] Praly, J.P., Stefano, C.D. and Smosak, L. (2000) Photolysis of Glycopyranosyl Azides C-1 Substituted by Cyanoamido. Tetradron, 11, 533-537.

[4] Wolfe, J.P., Rennels, R.A. and Buchwald, S.L. (1996) Intramolecular Palladium-Catalyzed Aryl Amination and Aryl Amidation. Tetrahedron, 52, 7525-7546.

[5] Ma, C., Jie, S., Xin, L., Falck, J.R. and Shin, D.S. (2006) Novel Formation of 1,3Oxazepine Heterocylic via Palliadium-Catalyzed Intramolecular Coupling Reaction. Tetrahedron, 62, 9002-9009. https://doi.org/10.1016/j.tet.2006.07.009

[6] Tang, Y., Fettinger, J.C. and Shaw, J.T. (2008) One-Step Synthesis of Complex Nitrogen Heterocyclic from Imines and Alkyl-Substituted Maleic Anhydrides. Organic Letters, 11, 7983-7991.

[7] Hanoon, H.D. (2011) Synthesis and Characterization of New Sevev-Membered Heterocyclic Compounds from Reaction of New Schiff Bases with Maleic and Phthalic Anhydrides. National Journal of Chemistry, 41, 44-89.

[8] Shaimaa, A., Ahmad, J.M. and Hassan, T. (2015) Synthesis and Identification of Some Derivatives of 1,3,4-Thiadiazole. Journal of Chemical and Pharmaceutical Research, 10, 1000-1011.

[9] Ayad, K., Israa, B. and Hyder, J. (2015) Synthesis, Characterization of Some New Azo Compounds Containing 1,3-Oxazepine, Anthraquinone Moieties and Studying Their Activity against Pathogenic Bacteria. Journal of Natural Sciences Research, 15, 69-80.

[10] Nagham, M. (2013) Preparation and Identification of Macrocycles of Oxazepine Compounds. Journal of Scientific and Innovative Research, 2, 53-60.

[11] Atyaf, Y. and Nasreen J. (2016) Synthesis and Characterization a New 1,3-Oxazepine Compound from New Bis-4-Amino-3-Mercapto-1,2,4-Triazole Derivatives. Organic Chemistry. An Indian Journal, 12.

[12] Verma, P., Gupta, S. and Yadav, V.S. (2015) Catalyst-Free and Facile Green Synthesis of Some Novel Oxazepine Derivatives. Der Chemica Sinica, 6, 86-89.

[13] Ayad, H. (2012) Microwave Synthesis of Some New 1,3-Oxazepine Compounds as Photostabilizing Additives for Pmma Films. Journal of Al-Nahrain University, 15, 47-59.

[14] Agirbas, H., Kemal, B. and Budak, F. (2011) Synthesis and Structure-Antibacterial Activity Relationship Studies of 4-Substituted phenyl-4,5-dihydrobenzo[f][1,4]oxazepin-3(2H)-thiones. Medicinal Chemistry Research, 20, 1170-1180. 
https://doi.org/10.1007/s00044-010-9457-4

[15] Serrano-Wu, M.H., St. Laurent, D.R., Chen, Y., Huang, S., Lam, K.R., et al. (2002) Sordarin Oxazepine Derivatives as Potent Antifungal Agents. Bioorganic \& Medicinal Chemistry Letters, 12, 2757-2760. https://doi.org/10.1016/S0960-894X(02)00529-2

[16] Abedel-Hahez, A.A. and Abdel-Wahab, B.A. (2008) 5-(4-Chlorophenyl)-5,6-dihydro-1,3-oxazepin-7(4H)-one Derivatives as Lipophilic Cyclic Analogues of Baclofen: Design, Synthesis, and Neuropharmacological Evaluation. Bioorganic \& Medicinal Chemistry, 16, 7983-7991. https://doi.org/10.1016/j.bmc.2008.07.064

[17] Hallinan, E.A., Hagen, T.J., Tsymbalov, S., Husa, R.K., Lee, A.C., Stapelfeld, A. and Savage, M.A. (1996) Aminoacetyl Moiety as a Potential Surrogate for Diacylhydrazine Group of SC-51089, a Potent PGE2 Antagonist, and Its Analogs. Journal of Medicinal Chemistry, 39, 609-613. https://doi.org/10.1021/jm950454k

[18] Kubota, K., Kurebayashi, H., Miyachi, H., Tobe, M., Onishi, M. and Isobe, Y. (2011) Synthesis and Structure-Activity Relationship of Tricyclic Carboxylic Acid as Novel Anti-Histamines. Bioorganic \& Medicinal Chemistry, 19, 3005-3021. https://doi.org/10.1016/j.bmc.2011.03.003

[19] Bajajt, K., Srivastava, V.K. and Kumar, A. (2003) Synthesis of 1,5-Benzothia/Oxazepine as Potent Neuroleptic Agents. Indian Journal of Chemistry. Section B: Organic Chemistry, Including Medical Chemistry, 42, 1149-1155.

[20] Katritzky, A.R., Cai, C., Suzuki, K. and Singh, S.K. (2004) Facile Syntheses of Oxazolines and Thiazolines with $\mathrm{N}$-Acylbenzotriazoles under Microwave Irradiation. The Journal of Organic Chemistry, 69, 811-814. https://doi.org/10.1021/jo0355092

[21] Katritzky, A.R., Majumder, S. and Ritu, J. (2003) Microwave assisted N-Chlorination of Secondary Amide. ARKIVOC, xii, 74-79.

[22] Patel, V.M. and Desai, K.R. (2004) Ecofriendly Synthesis of Fluorine-Containing Pyrazoline Derivatives over Potassium Carbonate. ARKIVOC, i, 123-129.

[23] Nuchter, M., Ondruschka, B., Bonrath, W. and Gum, A. (2004) Microwave Assisted Synthesis-A Critical Technology Overview. Green Chemistry, 6, 128-141. https://doi.org/10.1039/B310502D

[24] Loupy, A. (2002) Microwave in Organic Synthesis. Wiley-VCH, Weinheim, Germany. https://doi.org/10.1002/3527601775

[25] Boruah, B., Boruah, J., Prajapati, D.M., Sandhu, J.C. and Gosh, A.C. (1996) Microwave-Induced 1,3-Dipolar Cycloaddition of 2-Aroyl-Aziridines. Tetrahedron Letters, 37, 4203-4204. https://doi.org/10.1016/0040-4039(96)00795-2

[26] Tanaka, K. (2003) Solvent-Free Organic Synthesis. Wiley-VCH, Weinheim, Germany. https://doi.org/10.1002/3527601821

[27] Al-Bayati, R.I., Al-Amiery, A.A.H. and Al-Majedy, Y.K. (2010) Design, Synthesis and Bioassay of Novel Coumarins. African Journal of Pure and Applied Chemistry, 4, 74-86. 
Submit or recommend next manuscript to SCIRP and we will provide best service for you:

Accepting pre-submission inquiries through Email, Facebook, LinkedIn, Twitter, etc. A wide selection of journals (inclusive of 9 subjects, more than 200 journals)

Providing 24-hour high-quality service

User-friendly online submission system

Fair and swift peer-review system

Efficient typesetting and proofreading procedure

Display of the result of downloads and visits, as well as the number of cited articles Maximum dissemination of your research work

Submit your manuscript at: http://papersubmission.scirp.org/

Or contact ijoc@scirp.org 